\title{
Assessment of horizontal seismic coefficient for gravity quay walls by centrifuge tests
}

\author{
M.-G. LEE*, J.-G. HA*, S.-B. JO†, H.-J. PARK* and D.-S. KIM*
}

\begin{abstract}
In the simplified analysis of seismic design of gravity quay walls based on the pseudo-static approach, selection of an appropriate horizontal seismic coefficient $\left(k_{h}\right)$ is important for computing the equivalent pseudo-static inertial force. However, there is no unified standard for defining $k_{\mathrm{h}}$. There are conflicts among the existing $k_{\mathrm{h}}$ definitions regarding whether it considers (a) the effect of wall height on maximum horizontal acceleration (MHA) used in the determination of $k_{\mathrm{h}}$ or $(b)$ the application of correction factor for $k_{\mathrm{h}}$ according to seismic performance grade. This paper evaluates the relevance of these conflicts by initially reviewing the $k_{\mathrm{h}}$ definitions in the existing codes and guidelines for port structures and then by performing a series of dynamic centrifuge tests on caisson gravity quay walls of different wall heights $(5,10$ and $15 \mathrm{~m})$. A review of the existing codes and guidelines has shown that the correction factor for $k_{\mathrm{h}}$ should be specified according to the seismic performance grade for the economical design of quay walls. On the other hand, based on the centrifuge tests, it was found that the MHA used in $k_{\mathrm{h}}$ calculation and the correction factor for considering seismic performance grade should reflect the effect of wall height.
\end{abstract}

KEYWORDS: centrifuge modelling; earthquakes; standards \& codes of practice

ICE Publishing: all rights reserved

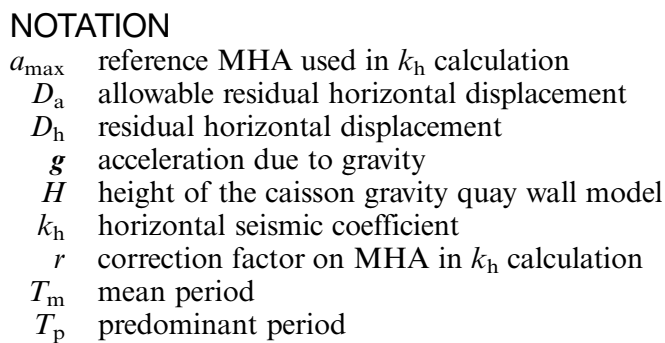

\section{INTRODUCTION}

The conventional procedures for seismic design and seismic stability evaluation of quay walls rely on a simplified method of analysis based on the pseudo-static method. In this method, Coulomb's earth pressure theory is adopted to estimate the active thrust behind the wall. The effects of earthquake on the calculation of active thrust are considered through the Mononobe-Okabe (M-O) (Okabe, 1924; Mononobe \& Matsuo, 1929) and Seed-Whitman (Seed \& Whitman, 1970) methods.

In the $\mathrm{M}-\mathrm{O}$ method, $k_{\mathrm{h}}$, expressed in terms of acceleration due to gravity, is used to convert the real dynamic behaviour to an equivalent pseudo-static inertial force for analysis and design. Therefore, the selection of an appropriate $k_{\mathrm{h}}$ is critical for representing the real dynamic behaviour. However, there is no unified standard for defining $k_{\mathrm{h}}$. The port structure designers in Korea had difficulty in choosing a suitable $k_{\mathrm{h}}$ definition, as there are conflicts in defining $k_{\mathrm{h}}$ between the seismic design code (MOF, 2014) and the

Manuscript received 20 January 2017; first decision 3 April 2017; accepted 15 May 2017.

Published online at www.geotechniqueletters.com on 8 June 2017.

*Department of Civil and Environmental Engineering, KAIST, Daejeon, Korea.

†Infrastructure Research Centre, K-water Institute, Daejeon, Korea. seismic performance evaluation code (MLTM, 2012) of port structures. The disagreement between definitions can be related to the reference point of MHA used in the determination of $k_{\mathrm{h}}$ according to the wall height, and whether it considers the application of correction factor for $k_{\mathrm{h}}$. Similar conflicts in $k_{\mathrm{h}}$ definitions also exist in other codes and guidelines (Werner, 1998; MOT, 1999; CEN, 2004). Thus, the definitions of $k_{\mathrm{h}}$ need to be experimentally evaluated for resolving these conflicts, so that a standard definition is possible for future design guidelines using the simplified analysis method (Bolton \& Steedman, 1985; Veletsos \& Younan, 1997; Iai \& Sugano, 2000; Dakoulas \& Gazetas, 2008; OCDI, 2009; Bellezza et al., 2011; MOF, 2014; Jo et al., 2017).

In this study, the key considerations to be included in $k_{\mathrm{h}}$ definition were deduced through a review of the existing codes and guidelines for port structures. Then, three dynamic centrifuge tests were performed with different wall heights $(5,10$ and $15 \mathrm{~m}$ at prototype scale) to verify the influence of these considerations on $k_{\mathrm{h}}$ calculation.

\section{REVIEW OF $K_{\mathrm{H}}$ DEFINITIONS}

To identify the major considerations for defining $k_{\mathrm{h}}$, the existing codes and guidelines for port structures were reviewed. The following two major concerns for defining $k_{\mathrm{h}}$ were then deduced.

- Effect of wall height on reference MHA used in $k_{\mathrm{h}}$ calculation.

- Application of correction factor on MHA used in $k_{\mathrm{h}}$ calculation according to the seismic performance grade classified by the level of acceptable damage (i.e. allowable residual horizontal displacement at the top of the wall, $D_{\mathrm{a}}$ ).

An overview of the $k_{\mathrm{h}}$ definitions with respect to the aforementioned considerations is summarised in Table 1. 
Table 1. Overview of representative seismic coefficient $\left(k_{h}\right)$ definitions

\begin{tabular}{|c|c|c|c|c|c|c|}
\hline \multirow[t]{2}{*}{ Codes/guidelines } & \multirow[t]{2}{*}{ Equations } & \multirow{2}{*}{\multicolumn{3}{|c|}{ Correction factor $(r)$}} & \multicolumn{2}{|c|}{ Reference MHA $\left(a_{\max }\right)$} \\
\hline & & & & & $H^{*}$ over $10 \mathrm{~m}$ & $H$ under $10 \mathrm{~m}$ \\
\hline CEN (2004) & $k_{\mathrm{h}}=\frac{1}{r} \frac{a_{\max }}{g}$ & $\begin{array}{l}2 \\
1 \cdot 5 \\
1\end{array}$ & \multicolumn{2}{|c|}{$\begin{array}{l}\text { Free gravity walls that can } \\
\text { accept a displacement of up } \\
\text { to } D_{\mathrm{a}}=300 \cdot a_{\max }(\mathrm{mm}) \\
\text { Free gravity walls that can } \\
\text { accept a displacement of up } \\
\text { to } D_{\mathrm{a}}=200 \cdot a_{\max }(\mathrm{mm}) \\
\text { Flexural reinforced concrete } \\
\text { walls, anchored or braced } \\
\text { walls, reinforced concrete } \\
\text { walls founded on vertical } \\
\text { piles }\end{array}$} & Average MHA & Base MHA \\
\hline MOF (2014) & $k_{\mathrm{h}}=\frac{1}{r} \frac{a_{\mathrm{max}}}{\boldsymbol{g}}$ & $\begin{array}{l}2 \\
1\end{array}$ & \multicolumn{2}{|c|}{$\begin{array}{l}D_{\mathrm{a}}=300(\mathrm{~mm}) \\
D_{\mathrm{a}}=0(\mathrm{~mm})\end{array}$} & Surface MHA & Base MHA \\
\hline MOT (1999) and Werner (1998) & $\begin{array}{l}k_{\mathrm{h}}=\frac{1}{r}\left(\frac{a_{\max }}{\boldsymbol{g}}\right)^{1 / r} \\
k_{\mathrm{h}}=r \frac{a_{\max }}{\boldsymbol{g}}\end{array}$ & $\begin{array}{l}1 \\
3 \\
0 \cdot 6\end{array}$ & $\begin{array}{l}a_{\max }<0 \cdot 2 \\
a_{\max }>0 \cdot 2 \\
\text { Class } \mathrm{B} \dagger\end{array}$ & Special class $\dagger$ & \multicolumn{2}{|l|}{ Surface MHA } \\
\hline MLTM (2012) & $k_{\mathrm{h}}=\frac{a_{\max }}{\boldsymbol{g}}$ & N/A & N/A & & Average MHA & \\
\hline
\end{tabular}

* $H$ denotes wall height.

$\dagger$ Detailed in the technical standards for ports and harbour facilities in Japan (MOT, 1999).

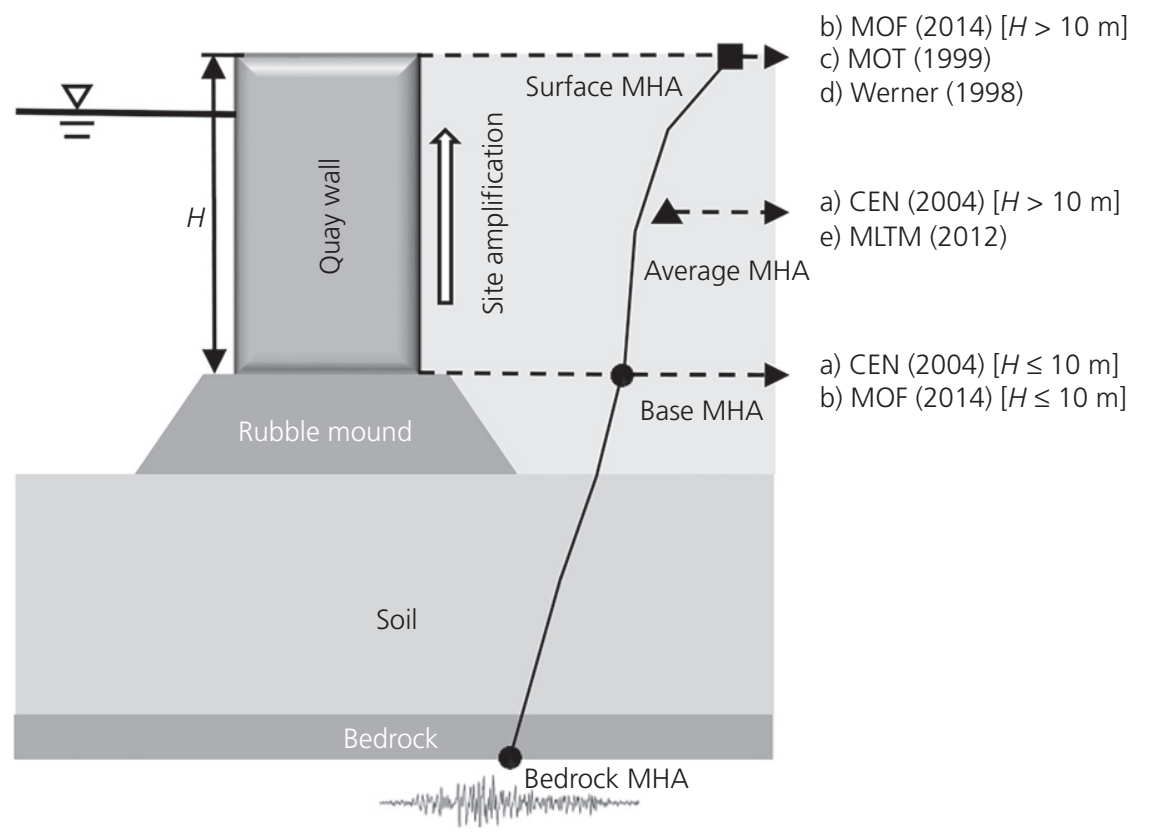

Fig. 1. The locations of reference MHA used for the calculation of $k_{\mathrm{h}}$

Furthermore, the locations of reference MHA $\left(a_{\max }\right)$ used in calculating $k_{\mathrm{h}}$ based on each definition are shown in Fig. 1.

The $k_{\mathrm{h}}$ definitions in CEN (2004) and MOF (2014) reflect both the major concerns. To consider the effect of wall height on $k_{\mathrm{h}}$, the location of $a_{\mathrm{max}}$ is specified based on the wall height of $10 \mathrm{~m}$. Meanwhile, the guidelines from Werner (1998) and MOT (1999) adopted the $k_{\mathrm{h}}$ definition from the study by Noda et al. (1975). These guidelines apply a correction factor to MHA according to the seismic performance grade, but it does not consider the effect of wall height. On the other hand, MLTM (2012) defines $k_{\mathrm{h}}$ as the average value of the MHA along the wall height at the backfill (average MHA), regardless of the seismic performance grade and wall height.

To visualise the influence of the above-mentioned considerations on $k_{\mathrm{h}}$, the $k_{\mathrm{h}}$ values from $k_{\mathrm{h}}$ definitions having similar seismic performance grade (corresponding cases are indicated by shaded values in Table 1) are plotted with respect to surface MHA in Fig. 2. As $a_{\max }$ is defined differently from code to code, it is necessary to obtain the corresponding values of base MHA and average MHA from the given surface MHA for comparison. The base MHA was calculated by dividing the surface MHA by the average amplification ratio of $1 \cdot 5$, which was deduced from a centrifuge test by Lee et al. (2013). Figure 2 shows that $k_{\mathrm{h}}$ 


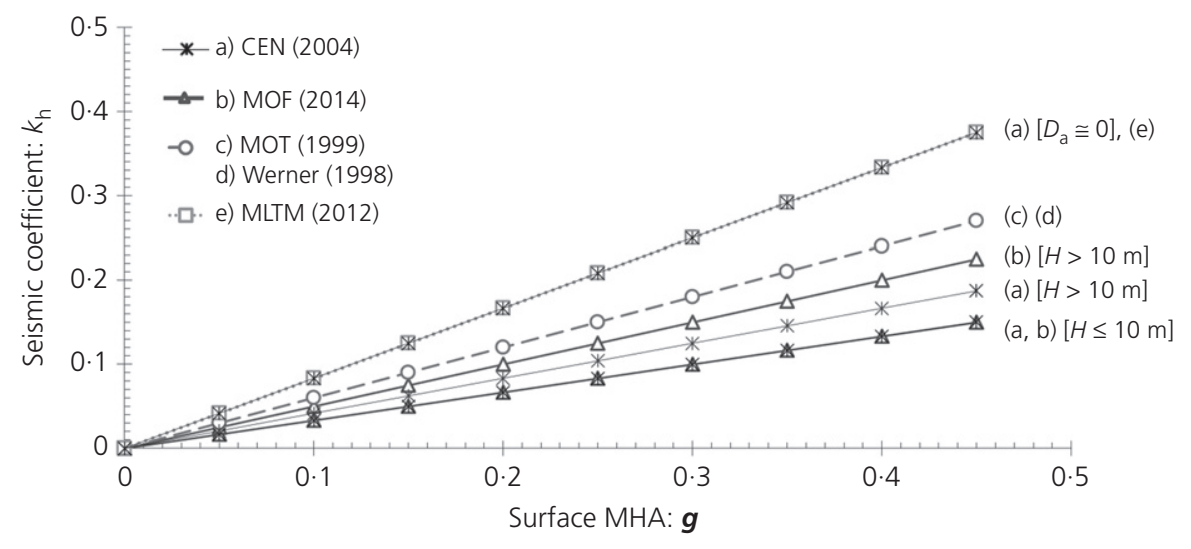

Fig. 2. The $k_{\mathrm{h}}$ values from the existing codes and guidelines according to surface MHA

values from CEN (2004) and MOF (2014), which reflects the aforementioned considerations, are estimated to be lower as compared with other guidelines. The $k_{\mathrm{h}}$ values from MLTM (2012), which does not reflect the above considerations, are same with the conservative $k_{\mathrm{h}}$ value from CEN (2004) applicable to the ideal case of restrained wall $\left(D_{\mathrm{a}} \cong 0\right)$. Hence, gravity quay walls designed according to MLTM (2012) need to use the same conservative $k_{\mathrm{h}}$ value regardless of the seismic performance grade. This implies that the correction factor according to seismic performance grade should be applied to MHA used in $k_{\mathrm{h}}$ calculation for an economical design of gravity quay walls.

\section{DYNAMIC CENTRIFUGE MODELLING}

Three dynamic centrifuge tests were carried out on caisson gravity quay wall models for different wall heights to verify the effect of wall height on MHA used in the calculation of $k_{\mathrm{h}}$ and the correction factor values used in the $k_{\mathrm{h}}$ definitions. The experiments were conducted at the KOCED Geo-Centrifuge Testing Centre at KAIST using an earthquake simulator mounted on the centrifuge (Kim et al., 2013a, 2013b). An equivalent shear beam (ESB) model box, which minimises the boundary effect on the soil, was used for dynamic centrifuge tests (Lee et al., 2013). The centrifugal accelerations used were $40 \mathrm{~g}$ for 5 and $10 \mathrm{~m}$ walls, and $60 \mathrm{~g}$ for $15 \mathrm{~m}$ wall. All results are presented in prototype units.

\section{Model structures}

The caisson gravity quay wall models were designed with a $k_{\mathrm{h}}$ value of 0.13 based on a simplified quay wall design provided by MOF (2014). The models used in the experiments were made of aluminium alloy (T6061). Among the three seismic performance evaluation criteria (sliding, overturning and bearing capacity failure), sliding was set to be the first failure mode. A factor of safety of 1 was achieved in the pseudo-static force equilibrium equation with a $k_{\mathrm{h}}$ of 0.13 and other experimental conditions and the weight of the quay wall was determined. The required weight of walls was obtained by adjusting the thickness of aluminium considering the scaling law. The specifications of model structures are summarised in Table 2.

\section{Model ground}

The rubble mound and backfill were constructed by two types of dry silica sand with different mean diameters. The physical properties of the sand are presented in Table 3.
Table 2. Specifications of caisson gravity quay wall models (all values are presented in prototype scale)

\begin{tabular}{l|r|c|c}
\hline & Model A & Model B & Model C \\
\hline Height: $\mathrm{m}$ & 5 & 10 & 15 \\
Breadth: $\mathrm{m}$ & $2 \cdot 85$ & $5 \cdot 7$ & $8 \cdot 55$ \\
Length*: $\mathrm{m}$ & $19 \cdot 48$ & $19 \cdot 48$ & $29 \cdot 22$ \\
Weight: $\mathrm{t}$ & 106 & 424 & 1436 \\
\hline
\end{tabular}

*All the walls spanned the length of the container (i.e. $487 \mathrm{~mm}$ at model scale, which is $2 \mathrm{~mm}$ shorter than the length of the container to eliminate friction).

Table 3. Physical properties of silica sand

\begin{tabular}{l|c|c}
\hline Properties & $\begin{array}{c}\text { Silica sand } \\
\text { (rubble mound) }\end{array}$ & $\begin{array}{c}\text { Silica } \\
\text { sand } \\
\text { (backfill) }\end{array}$ \\
\hline Unified soil classification & $\mathrm{SP}$ & $\mathrm{SP}$ \\
Median diameter $\left(D_{50}\right): \mathrm{mm}$ & $0 \cdot 80$ & $0 \cdot 22$ \\
Curvature coefficient $\left(C_{\mathrm{C}}\right)$ & $0 \cdot 98$ & $1 \cdot 11$ \\
Uniformity coefficient $\left(C_{\mathrm{U}}\right)$ & $1 \cdot 54$ & $1 \cdot 96$ \\
Specific gravity $\left(G_{\mathrm{S}}\right)$ & $2 \cdot 65$ & $2 \cdot 65$ \\
Plasticity index & $\mathrm{NP}$ & $\mathrm{NP}$ \\
Maximum unit weight: $\mathrm{kN} / \mathrm{m}^{3}$ & $14 \cdot 19$ & $16 \cdot 45$ \\
Minimum unit weight: $\mathrm{kN} / \mathrm{m}^{3}$ & $12 \cdot 87$ & $12 \cdot 44$ \\
\hline
\end{tabular}

The rubble mound was densified to a relative density of $86 \%$ by compaction for preventing overturning and bearing capacity failure. The peak friction angle of $43^{\circ}$ was obtained from the triaxial test, and the inter-friction angle between the rubble mound and the wall was about two-third of the peak friction angle in a direct shear test (Jo et al., 2014). The soil in the backfill was prepared using pluviation at a relative density of $80 \%$.

\section{Instrumentation}

MHA values at each depth in the backfill during earthquake excitations were obtained by accelerometers buried in the soil as shown in Fig. 3. The residual horizontal displacements of the wall $\left(D_{\mathrm{h}}\right)$ were measured by potentiometers. The occurrence of overturning of the wall was evaluated by measuring $D_{\mathrm{h}}$ at the top and the bottom of the wall. To measure the subsidence of backfill and to check the bearing capacity failure of rubble mound based on the settlement of the wall, two laser sensors were used. Acceleration and $D_{\mathrm{h}}$ were positive for the active directions, and the settlement was positive for the downward direction from the surface. 


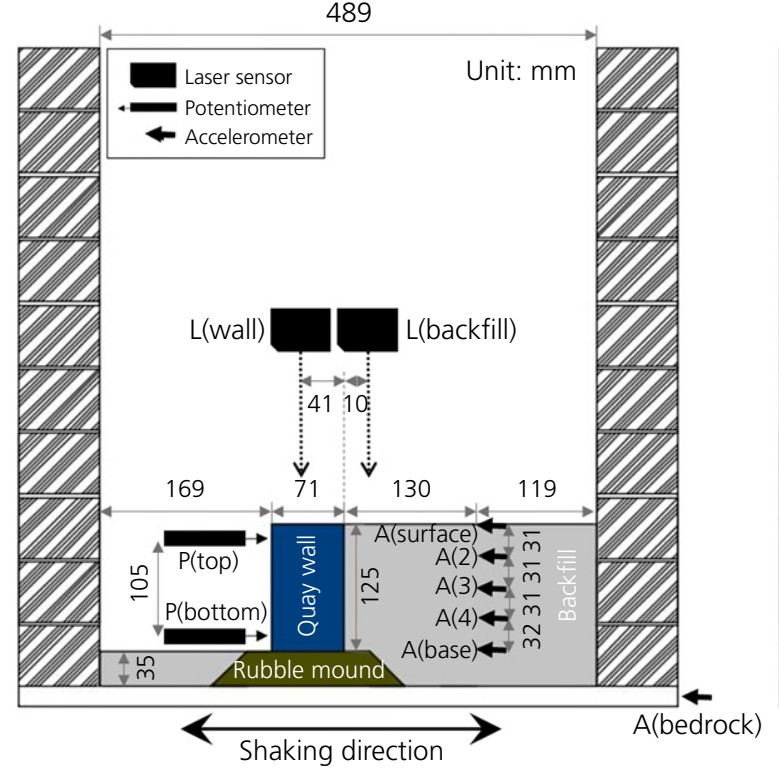

(a)

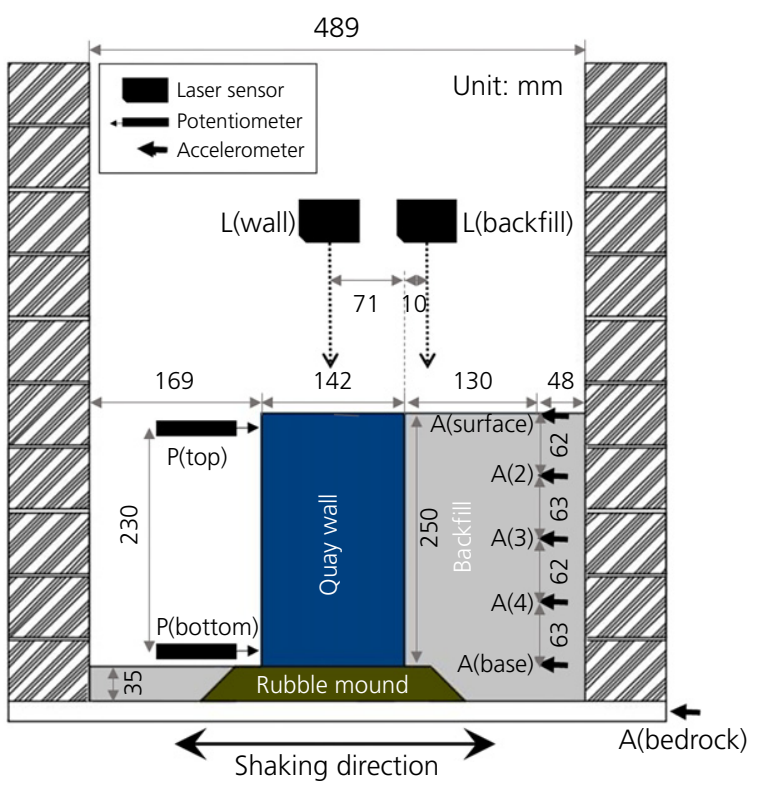

(b)

Fig. 3. Schematic illustration of test instrumentation: (a) $5 \mathrm{~m}$ wall height, (b) 10 and $15 \mathrm{~m}$ wall height (all dimensions are presented in model scale)

\section{Earthquake input motions}

The Ofunato earthquake was used as an input earthquake in which the predominant period $\left(T_{\mathrm{p}}\right)$ and the mean period $\left(T_{\mathrm{m}}\right)$ (Rathje et al., 1998) are 0.248 and $0.377 \mathrm{~s}$, respectively. This is a common feature of earthquakes occurring in shallow bedrock conditions in Korea, which has a short-period-dominated spectral region (Manandhar et al., 2017). The input earthquakes were applied incrementally in the range of $0.01-0.43 \mathrm{~g}$ at the base of the ESB container, which represented the bedrock motion.

\section{TEST RESULTS}

MHA profile in backfill at the moment of sliding failure

To check the overturning and bearing capacity failure and to determine the initial point of sliding failure, $D_{\mathrm{h}}$ from the top and bottom of the wall and the settlements of wall and backfill were measured simultaneously and are plotted with respect to the MHA at bedrock, as shown in Fig. 4. Fig. 4 follows the information provided in Fig. 3. According to the figure, the differences between the $D_{\mathrm{h}}$ values measured at the top and bottom of the wall are small, and the settlement of the wall was minimal for increasing bedrock MHA. This shows that the overturning and bearing capacity failures did not occur and there was only a horizontal movement of the wall.

The initial point for sliding failure was defined based on the assumption that the backfill is in a state of plastic equilibrium to produce minimum active pressure. This assumption is used conventionally in the stability evaluation of sliding failure according to the $\mathrm{M}-\mathrm{O}$ method. Considering this assumption, the point at which $D_{\mathrm{h}}$ starts to increase after the backfill attains the state of minimum active pressure based on Terzaghi's experiments (Terzaghi, $1941)$ is defined as the initial point of sliding failure. The corresponding $D_{\mathrm{h}}$ values are 5,10 and $15 \mathrm{~mm}$ for 5,10 and $15 \mathrm{~m}$ wall height, respectively, based on the $D_{\mathrm{h}} / H$ value of 0.001 applicable for dense sand. Also, when the backfill attains the state of minimum active pressure, the triangular soil wedge formed behind the wall fails (Das, 2015). The wedge failure can be implied from the relative settlement of the wall and backfill, and this can alternatively be chosen as the initial point of sliding failure. The two identified initial points of sliding failure occurred at the same bedrock MHA for each case of wall height, as indicated by the arrows in Fig. 4.

To assess the two major concerns in $k_{\mathrm{h}}$ definitions for different $a_{\max }$ and correction factor, the MHA values of the backfill along the wall height at the moment of sliding failure were measured by accelerometers embedded in the soil. The MHA profiles for the three cases of wall heights at the moment of sliding failure are shown in Fig. 5.

\section{Evaluation of two major considerations in defining $\mathrm{k}_{h}$}

The measured $a_{\max }$ values were substituted in $k_{\mathrm{h}}$ definitions having a seismic performance grade similar to the model structure (these cases are indicated by shaded values in Table 1). The obtained $k_{\mathrm{h}}$ were then compared for different codes/guidelines according to the wall height as summarised in Table 4. The percentage difference between the design $k_{\mathrm{h}}$ for the model structure $(0 \cdot 13)$ and the measured $k_{\mathrm{h}}$ was also determined.

From Table 4 , it is evident that in the case of 5 and $10 \mathrm{~m}$ walls, the design $k_{\mathrm{h}}(0 \cdot 13)$ value is similar to that obtained using half of the base MHA as suggested by CEN (2004) and MOF (2014). On the other hand, the definitions that did not consider the wall height in $k_{\mathrm{h}}$ calculation showed a big difference with the design $k_{\mathrm{h}}$. In the case of a $15 \mathrm{~m}$ wall, the design $k_{\mathrm{h}}$ value is comparable with the $k_{\mathrm{h}}$ obtained from average MHA and half of the surface MHA as proposed by CEN (2004) and MOF (2014), respectively. However, for all the codes, the measured $k_{\mathrm{h}}$ values for a wall of height $15 \mathrm{~m}$ showed less difference as compared with the case of a for wall of height equal to or less than $10 \mathrm{~m}$. Additionally, the correction factor of $2 \cdot 0$ used in CEN (2004) and MOF (2014), which consider wall height, provides a better estimate of design $k_{\mathrm{h}}$ than those used in MOT (1999) and MLTM (2012), which does not consider the wall height.

The simplified analysis, as adopted in the existing codes and guidelines, do not consider the effect of frequency content of earthquake, damping, soil non-linearity and wall 


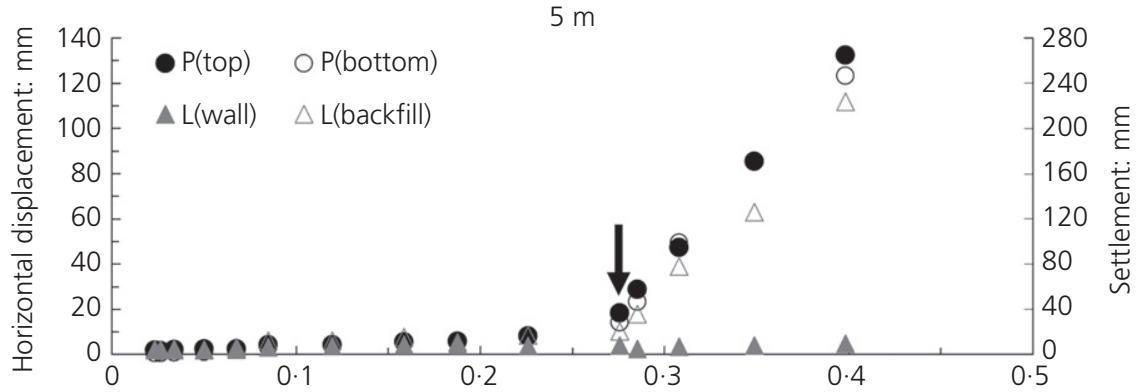

(a)

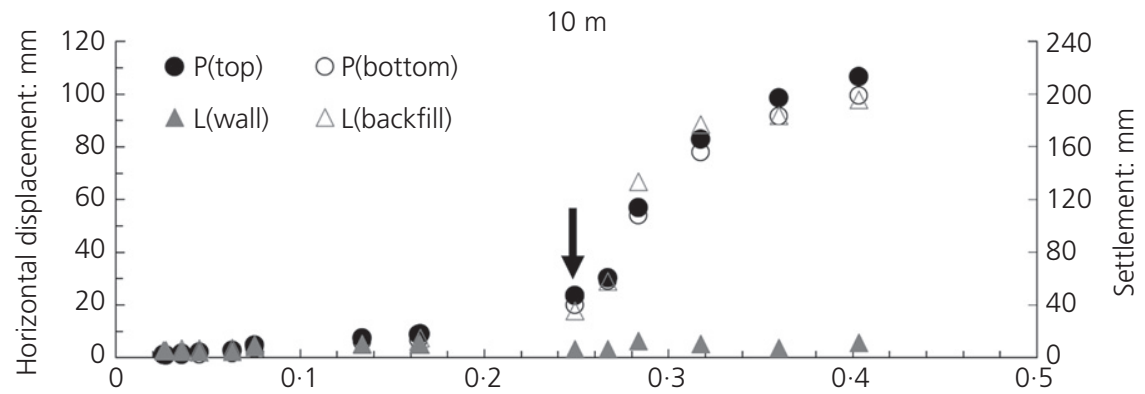

(b)

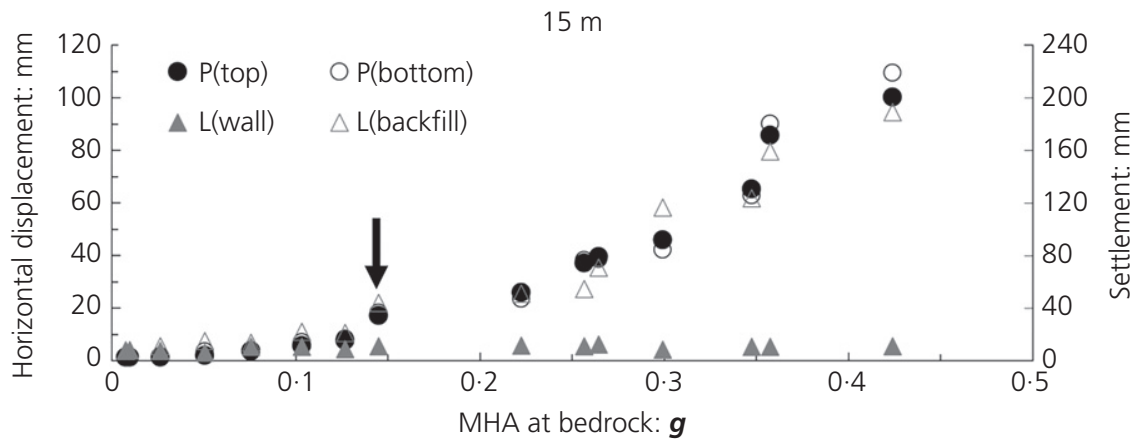

(c)

Fig. 4. Residual horizontal displacements of wall, and settlements of wall and backfill according to bedrock MHA: (a) $5 \mathrm{~m}$ wall height, (b) $10 \mathrm{~m}$ wall height, (c) $15 \mathrm{~m}$ wall height

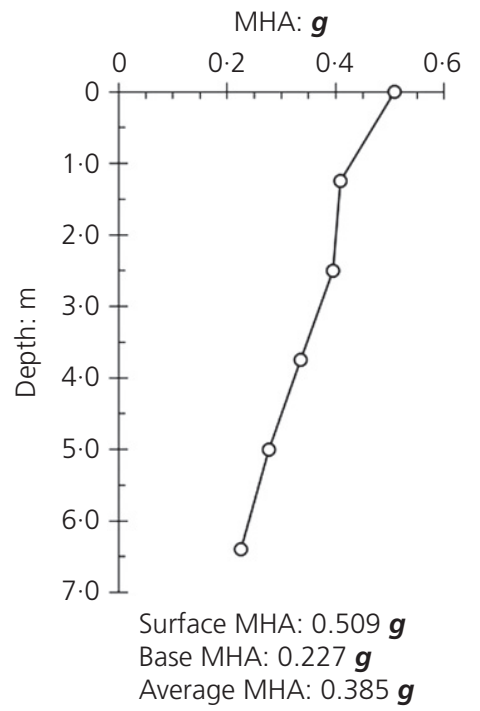

(a)

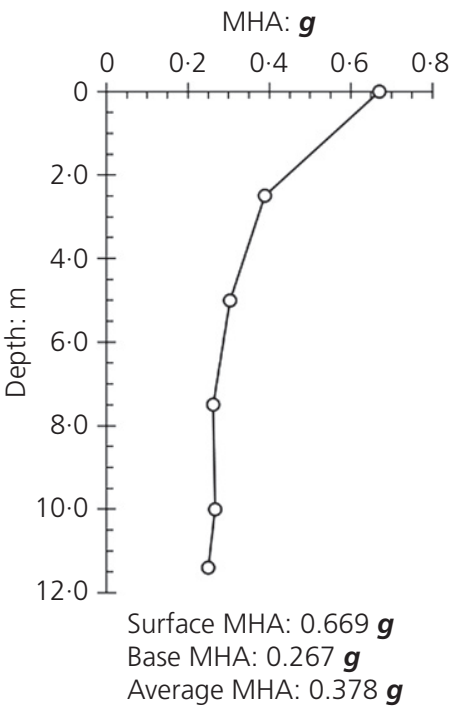

(b)

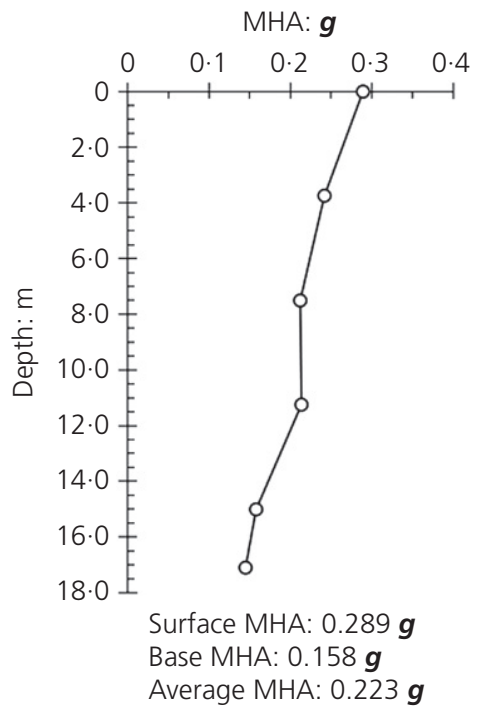

(c)

Fig. 5. MHA profile in backfill at the moment of sliding failure: (a) $5 \mathrm{~m}$ wall height, (b) $10 \mathrm{~m}$ wall height, (c) $15 \mathrm{~m}$ wall height 
Table 4. Comparison of the design $k_{\mathrm{h}}$ value with measured $k_{\mathrm{h}}$ values from centrifuge tests

\begin{tabular}{|c|c|c|c|c|c|}
\hline Codes/guidelines & Wall height: $\mathrm{m}$ & $k_{\mathrm{h}}$ definition & Design $k_{\mathrm{h}}$ & Measured $k_{\mathrm{h}}$ & Difference: $\%$ \\
\hline \multirow{4}{*}{ CEN (2004) } & 5 & 1 (basePGA) & \multirow{4}{*}{$0 \cdot 130$} & \multirow{2}{*}{$0 \cdot 114$} & \multirow{2}{*}{-12} \\
\hline & 5 & $\kappa_{\mathrm{h}}=\overline{2} \quad \boldsymbol{g}$ & & & \\
\hline & 10 & 1 (averagePGA) & & $0 \cdot 133$ & 2 \\
\hline & 15 & $k_{\mathrm{h}}=\frac{\pi}{2} \frac{}{g}$ & & $0 \cdot 112$ & -14 \\
\hline \multirow{3}{*}{ MOF (2014) } & 5 & $k_{\mathrm{h}}=\frac{1}{(\text { basePGA })}$ & \multirow{3}{*}{$0 \cdot 130$} & $0 \cdot 114$ & -12 \\
\hline & 10 & $2 \quad g$ & & $0 \cdot 133$ & 2 \\
\hline & 15 & $k_{\mathrm{h}}=\frac{1}{2} \frac{(\text { surfacePGA })}{\boldsymbol{g}}$ & & $0 \cdot 144$ & 11 \\
\hline \multirow{3}{*}{ MOT (1999) and Werner (1998) } & 5 & $k_{\mathrm{h}}=0.6 \frac{(\text { surfacePGA })}{}$ & \multirow{3}{*}{$0 \cdot 130$} & $0 \cdot 305$ & 135 \\
\hline & 10 & & & $0 \cdot 401$ & 208 \\
\hline & 15 & & & $0 \cdot 173$ & 33 \\
\hline \multirow[t]{3}{*}{ MLTM (2012) } & 5 & $k_{\mathrm{h}}=\underline{\text { (averagePGA) }}$ & \multirow[t]{3}{*}{$0 \cdot 130$} & $0 \cdot 385$ & 196 \\
\hline & 10 & $g$ & & $0 \cdot 378$ & 191 \\
\hline & 15 & & & $0 \cdot 223$ & 72 \\
\hline
\end{tabular}

translation. The limitations of the pseudo-static method based on $\mathrm{M}-\mathrm{O}$ were assessed by comparing the differences between pseudo-static and true dynamic behaviours in centrifuge tests by many researchers (Nakamura, 2006; Al Atik \& Sitar, 2010; Brandenberg et al., 2015; Hushmand et al., 2016; Wagner \& Sitar, 2016; Jo et al., 2014, 2017). In this regard, the definition of $k_{\mathrm{h}}$ could be further improved in future studies. In addition, the influence of excess pore water pressure developed in the backfill during earthquake should be evaluated for port structures (Zeng \& Steedman, 1993; Iai et al., 1998; Kim et al., 2005; Lee, 2005).

\section{CONCLUSIONS}

In this study, the existing codes and guidelines for port structures were reviewed and dynamic centrifuge tests were performed to identify and evaluate the two major considerations in $k_{\mathrm{h}}$ definition used in the simplified analysis method of designing gravity quay walls. It was found that the correction factor according to the seismic performance grade and the effect of wall height should be considered on MHA used in $k_{\mathrm{h}}$ calculation. Further, correction factors for the MHA used in $k_{\mathrm{h}}$ definition should be appropriately derived for different wall heights. This research has provided an important direction for arriving at a unified definition of $k_{\mathrm{h}}$ to be used in seismic codes and guidelines for the simplified analysis of gravity quay walls.

\section{ACKNOWLEDGEMENTS}

This research was part of the project titled 'Development of performance-based seismic design', funded by the Ministry of Oceans and Fisheries, Korea. This study was also supported by the National Research Foundation of Korea (NRF) grant funded by the Korea government (MSIP) (No. NRF-2015R1A2A1A15054531).

\section{REFERENCES}

Al Atik, L. \& Sitar, N. (2010). Seismic earth pressures on cantilever retaining structures. J. Geotech. Geoenviron. Engng, ASCE 136, No. 10, 1324-1333.

Bellezza, I., D'Alberto, D. \& Fentini, R. (2011). Design of rigid waterfront retaining walls in seismic conditions. Ital. Geotech. J., Spec. Issue-Seism. Des. Retrofitting 1, 47-62.

Bolton, M. D. \& Steedman, R. S. (1985). Modelling the seismic resistance of retaining structures. Proceedings of the 11 th international conference on soil mechanics and foundation engineering, San Francisco, CA, USA, pp. 1845-1848. Rotterdam, the Netherlands: Balkema.

Brandenberg, S. J., Mylonakis, G. \& Stewart, J. P. (2015). Kinematic framework for evaluating seismic earth pressures on retaining walls. J. Geotech. Geoenviron. Engng, ASCE 141, No. 7, 04015031 .

CEN (European Committee for Standardization) (2004). EN 1998-5: Eurocode 8: Design of structures for earthquake resistance. Part 5: foundations, retaining structures and geotechnical aspects. Brussels, Belgium: CEN.

Dakoulas, P. \& Gazetas, G. (2008). Insight into seismic earth and water pressures against caisson quay walls. Géotechnique 58, No. 2, 95-111, http://dx.doi.org/10.1680/geot.2008.58.2.95.

Das, B. M. (2015). Principles of foundation engineering. Independence, KY, USA: Cengage Learning.

Hushmand, A., Dashti, S., Davis, C., Hushmand, B., McCartney, J. S., Hu, J. \& Lee, Y. (2016). Seismic performance of underground reservoir structures: insight from centrifuge modeling on the influence of backfill soil type and geometry. J. Geotech. Geoenviron. Engng, ASCE 142, No. 11, 04016058.

Iai, S. \& Sugano, T. (2000). Shake table testing on seismic performance of gravity quay walls. Proceedings of the 12th world conference on earthquake engineering, Auckland, New Zealand, pp. 1-8. Upper Hutt, New Zealand: New Zealand Society for Earthquake Engineering.

Iai, S., Ichii, K., Liu, H. \& Morita, T. (1998). Effective stress analyses of port structures. Soils Found. 38, 97-114, http://dx.doi.org/10.3208/sandf.38.Special_97.

Jo, S. B., Ha, J. G., Yoo, M., Choo, Y. W. \& Kim, D. S. (2014). Seismic behavior of an inverted T-shape flexible retaining wall via dynamic centrifuge tests. Bull. Earthq. Engng 12, No. 2, 961-980.

Jo, S. B., Ha, J. G., Lee, J. S. \& Kim, D. S. (2017). Evaluation of the seismic earth pressure for inverted $\mathrm{T}$-shape stiff retaining wall in cohesionless soils via dynamic centrifuge. Soil Dyn. Earthq. Engng 92, 345-357, https://doi.org/10.1016/j.soildyn. 2016.10.009.

Kim, S. R., Jang, I. S., Chung, C. K. \& Kim, M. M. (2005). Evaluation of seismic displacements of quay walls. Soil Dyn. Earthq. Engng 25, No. 6, 451-459.

Kim, D. S., Kim, N. R., Choo, Y. W. \& Cho, G. C. (2013a). A newly developed state-of-the-art geotechnical centrifuge in Korea. J. Civ. Engng, KSCE 17, No. 1, 77-84.

Kim, D. S., Lee, S. H., Choo, Y. W. \& Perdriat, J. (2013b). Self-balanced earthquake simulator on centrifuge and dynamic performance verification. J. Civ. Engng, KSCE 17, No. 4, 651-661.

Lee, C. J. (2005). Centrifuge modeling of the behavior of caisson-type quay walls during earthquakes. Soil Dyn. Earthq. Engng 25, No. 2, 117-131.

Lee, S. H., Choo, Y. W. \& Kim, D. S. (2013). Performance of an equivalent shear beam (ESB) model container for dynamic 
geotechnical centrifuge tests. Soil Dyn. Earthq. Engng 44, 102-114, https://doi.org/10.1016/j.soildyn.2012.09.008.

Manandhar, S., Cho, H. I. \& Kim, D. S. (2017). Site classification system and site coefficients for shallow bedrock sites in Korea. J. Earthq. Engng, http://dx.doi.org/10.1080/13632469. 2016.1277570

MLTM (Ministry of Land, Transport and Maritime Affairs) (2012). Seismic performance evaluation \& improvement revision of existing structures (harbours). Sejong, Korea: Korea Infrastructures Safety and Technology Corporation (in Korean).

MOF (Ministry of Oceans and Fisheries) (2014). Ports and fishing harbours design code. Sejong, Korea: Ministry of Oceans and Fisheries (in Korean).

Mononobe, N. \& Matsuo, H. (1929). On the determination of earth pressures during earthquakes. Proceedings of the world engineering congress, vol. 9, pp. 177-185. Tokyo, Japan: World Engineering Congress.

MOT (Ministry of Transport) (1999). Technical standards for ports and harbour facilities in Japan. Tokyo, Japan: Japan Port and Harbour Association (in Japanese).

Nakamura, S. (2006). Reexamination of Mononobe-Okabe theory of gravity retaining walls using centrifuge model tests. Soils Found. 46, No. 2, 135-146.

Noda, S., Uwabe, T. \& Chiba, T. (1975). Relation between seismic coefficient and ground acceleration for gravity wall. Rep. Port Harbour Res. Inst. 14, No. 4, 67-111 (in Japanese).

OCDI (Overseas Coastal Area Development Institute) (2009). Technical standards and commentaries for port and harbour facilities in Japan. Tokyo, Japan: Overseas Coastal Area Development Institute.

Okabe, S. (1924). General theory of earth pressure and seismic stability of retaining wall and dam. J. Jpn. Soc. Civ. Engng, JSCE 10, No. 6, 1277-1323.

Rathje, E. M., Abrahamson, N. A. \& Bray, J. D. (1998). Simplified frequency content estimates of earthquake ground motions. J. Geotech. Geoenviron. Engng, ASCE 124, No. 2, $150-159$.

Seed, H. B. \& Whitman, R. V. (1970). Design of earth retaining structures for dynamic loads. ASCE specialty conference, lateral stresses in the ground and design of earth retaining structures, pp. 103-147. New York, NY, USA: ASCE.

Terzaghi, K. (1941). General wedge theory of earth pressure. $A S C E$ Trans. 106, 68-97.

Veletsos, A. S. \& Younan, A. H. (1997). Dynamic response of cantilever retaining walls. J. Geotech. Geoenviron. Engng, ASCE 123, No. 2, 161-172.

Wagner, N. \& Sitar, N. (2016). On seismic response of stiff and flexible retaining structures. Soil Dyn. Earthq. Engng 91, 284-293, https://doi.org/10.1016/j.soildyn.2016.09.025.

Werner, S. D. (1998). Seismic guidelines for ports. Reston, VA, USA: Technical Council on Lifeline Earthquake Engineering (TCLEE), ASCE.

Zeng, X. \& Steedman, R. S. (1993). On the behaviour of quay walls in earthquakes. Géotechnique 43, No. 3, 417-431, http://dx.doi.org/10.1680/geot.1993.43.3.417.

\section{HOW CAN YOU CONTRIBUTE?}

To discuss this paper, please submit up to 500 words to the editor at journals@ice.org.uk. Your contribution will be forwarded to the author(s) for a reply and, if considered appropriate by the editorial board, it will be published as a discussion in a future issue of the journal. 